\title{
Survival of Salmonella spp. on the Surfaces of Fresh Tomatoes and Selected Packing Line Materials
}

\author{
Raina L. Allen ${ }^{1}$, Benjamin R. Warren², Douglas L. Archer², \\ Steven A. Sargent ${ }^{3}$, and Keith R. Schneider ${ }^{2,4}$
}

ADDITIONAL INDEX WORDS. recovery, temperature, relative humidity, produce

Summary. Multi-state outbreaks of salmonellosis due to the consumption of contaminated fresh tomatoes (Lycopersicon esculentum) have recently occurred in the United States. This study investigated the survival of a five-serovar (serotype) Salmonella cocktail artificially inoculated onto tomato and packing line surfaces when held at various temperature and relative humidity $(\mathrm{RH})$ combinations over 28 days. Packinghouse surfaces included stainless steel, polyvinyl chloride (PVC), sponge rollers, conveyor belts, and unfinished oak wood surfaces. Packinghouse climates were generated to simulate conditions in Florida during late spring (30 $\left.{ }^{\circ} \mathrm{C} / 80 \% \mathrm{RH}\right)$ and fall/winter $\left(20^{\circ} \mathrm{C} / 60 \% \mathrm{RH}\right)$ months. Additionally, survival of Salmonella on tomatoes in standard ripening room conditions $\left(20{ }^{\circ} \mathrm{C} / 90 \% \mathrm{RH}\right)$ was evaluated. Recovery of inocula was by a vigorous shake/hand rub method. After 28 days, Salmonella populations remained detectable on tomato surfaces regardless of environmental conditions. Inoculated Salmonella populations tested at spring conditions declined to undetectable levels on all packing line materials by day 11 , with the exception of the unfinished oak, which reached undetectable levels by day 21 . In contrast, inoculated Salmonella populations tested at fall/ winter conditions declined to undetectable levels on sponge rollers and conveyor belts by day 7 and day 21, respectively. Stainless steel, PVC, and wood surfaces supported the survival of detectable populations of Salmonella over the 28-day sampling period. Results of this study demonstrate the potential for Salmonella to persist on tomato and packing line surfaces under common environmental conditions.

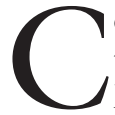
onsumption of fresh-market tomatoes in the United States has increased due to the increasing popularity of salads, salad bars, and sandwiches dressed with tomatoes (Lucier et al., 2000). Florida produces more fresh-market tomatoes than any other state and is second only to California in total tomato production (U.S. Department of Agriculture, 2004). Florida's tomato season extends from October to June. Most tomato production occurs in the months of November to January and again from April to May. Fresh-market tomatoes

${ }^{1}$ Del Monte Fresh Produce Co., 3306 Sydney Road, Plant City, FL 33567-1181.

${ }^{2}$ Food Science and Human Nutrition Department, University of Florida, 359 FHSN Bldg., Newell Dr., Gainesville, FL 32611-0370.

${ }^{3}$ Horticultural Sciences Department, University of Florida, PO Box 110690, Gainesville, FL 32611-0690.

${ }^{4}$ To whom reprint requests should be addressed; phone: 352.392.1991, ext 313; fax: 352.392.9467; email: krschneider@ifas.ufl.edu

Acknowledgments. This work was funded by USDACSREES IFAFS Grant number 00-52102-9637. This is Florida Agricultural Experiment Station Journal Series number R-10829. are available year-round in the U.S. because of imports and Florida's winter crops. Imported commodities are usually shipped to markets in the western states and Florida's winter crops are shipped to the eastern half of the nation (USDA, 2004).

According to the Centers for Disease Control and Prevention's (CDC), Emerging Infections Program, Foodborne Diseases Active Surveillance Network (FoodNet), Salmonella was the most prevalent foodborne pathogen reported in 2003 (CDC, 2004a). Furthermore, a total of 44,264 laboratory-confirmed cases of Salmonella were reported by the National Notifiable Diseases Surveillance System (NNDSS) in 2002 (CDC, 2004b). In recent years, Salmonella has been linked to numerous foodborne outbreaks associated with produce. Raw mung bean sprouts (Vigna radiata) (O'Mahoney et al., 1990), melons (Cucumis melo) (Blostein, 1991; CDC, 1979; Gayler, et al. 1955), and tomatoes (CDC, 2002; Cummings et al., 2001; Hedburg et al., 1999) have all been implicated in Salmonella outbreaks.

Several previous studies have investigated the survival of Salmonella on produce. Golden et al. (1993) demonstrated growth of Salmonella on rind-free pieces of watermelon (Citrullus lanatus), cantaloupe (C. melovar. cantalupensis), and honeydew (C. melo var. inodorus) over $24 \mathrm{~h}$ at $23{ }^{\circ} \mathrm{C}$. Guo et al. (2001) inoculated flowers and stems of tomato plants with Salmonella before and after fruit set and successfully isolated Salmonella from $37 \%$ of red, ripe tomatoes 21 to $49 \mathrm{~d}$ later. Zhuang et al. (1995) observed no significant change in inoculated $S$. enterica ser. Montevideo ( $S$. Montevideo) populations on tomato surfaces when held at $10{ }^{\circ} \mathrm{C}$ and $45 \%$ to $60 \%$ $\mathrm{RH}$ for $18 \mathrm{~d}$. Furthermore, growth of $S$. Montevideo was reported in chopped ripe tomatoes held at 20 or $30{ }^{\circ} \mathrm{C}$ (Zhuang et al., 1995). In two separate studies, Guo et al. (2001, 2002 ) demonstrated a 4-log decrease in inoculated Salmonella populations on mature, green tomatoes over $14 \mathrm{~d}$ at $20{ }^{\circ} \mathrm{C}$ and $70 \% \mathrm{RH}$. Lukasik et al. (2001) demonstrated that recovery of inoculated $S$. Montevideo on mature, red 'Roma' tomatoes (Lycopersicon esculentum var. pyriforme) was higher from artificial surface scars and stem and blossom scars then from intact tomato surfaces. Finally, postharvest multiplication of pathogenic bacteria on produce has been reported given a permissive temperature and relative humidity (Abdul-Raouf et al., 1993).

This study investigated the survival of a five-serovar Salmonella cocktail artificially inoculated onto tomato and surface materials typically contacting tomatoes during handling and packing at various temperature and relative humidity combinations over

\begin{tabular}{llll}
\hline $\begin{array}{l}\text { Units } \\
\begin{array}{l}\text { To convert U.S. to SI, } \\
\text { multiply by }\end{array}\end{array}$ & U.S. unit & SI unit & $\begin{array}{l}\text { To convert SI to U.S., } \\
\text { multiply by }\end{array}$ \\
\hline 29,574 & $\mathrm{fl} \mathrm{oz}$ & $\mu \mathrm{L}$ & $3.3814 \times 10^{-5}$ \\
29.5735 & $\mathrm{fl} \mathrm{oz}$ & $\mathrm{mL}$ & 0.0338 \\
2.5400 & inch $(\mathrm{es})$ & $\mathrm{cm}$ & 0.3937 \\
25.4000 & inch $(\mathrm{es})$ & $\mathrm{mm}$ & 0.0394 \\
1 & $\mathrm{ppm}$ & $\mu \mathrm{\mu g} \cdot \mathrm{g}^{-1}$ & 1 \\
$\left({ }^{\circ} \mathrm{F}-32\right) \div 1.8$ & ${ }^{\circ} \mathrm{F}$ & ${ }^{\circ} \mathrm{C}$ & $\left(1.8 \times{ }^{\circ} \mathrm{C}\right)+32$
\end{tabular}


28 d. Materials studied were stainless steel, PVC, sponge rollers, conveyor belts, and unfinished oak wood. Typical packinghouse facilities in Florida are open-sided, shed-like buildings, therefore temperature and relative humidity was controlled to simulate conditions in Florida during the warm, late spring $\left(30^{\circ} \mathrm{C} / 80 \% \mathrm{RH}\right)$ and cooler, fall/winter $\left(20^{\circ} \mathrm{C} / 60 \% \mathrm{RH}\right)$ tomato production seasons. Additionally, survival of Salmonella on tomatoes was evaluated in standard ripening room conditions $\left(20{ }^{\circ} \mathrm{C} / 90 \% \mathrm{RH}\right)$.

\section{Materials and methods}

ENVIRONMENTAL CLIMATE CONDITIONS IN FlORIDA. Climate conditions to simulate an open-air packinghouse environment during the Florida spring and fall/winter tomato production seasons were estimated using weather archives obtained from the Florida Automated Weather Network (FAWN) (University of Florida, 2004). The average documented temperature and relative humidity conditions calculated from the 2001 and 2002 data (Quincy, Fla.) were $30{ }^{\circ} \mathrm{C} / 80 \% \mathrm{RH}$ and 20 ${ }^{\circ} \mathrm{C} / 60 \% \mathrm{RH}$ for the fall/winter and spring tomato production seasons, respectively. Standard ripening room conditions used in the tomato industry are $20{ }^{\circ} \mathrm{C} / 90 \% \mathrm{RH}$.

Temperature and relative humidity conditions were generated and maintained using a Caron 6030 environmental humidity chamber (Caron, Marietta, Ohio) equipped with a Whatlow Series 96 temperature and $\mathrm{RH}$ controller (Whatlow, Winona, Minn.) and a Caron CRS 101 water supply system, which delivered distilled water to the system.

ACQUiSITION AND MAINTENANCE OF BACTERIAL CUltures. The five Salmonella serovars used in this study were S. enterica ser. Agona LJH618 (alfalfa sprouts isolate), S. enterica ser. Gaminara LJH6l6 (orange juice isolate), S. enterica ser. Michigan LJH615 (cantaloupe isolate), $S$. Montevideo LJH614 (human isolate from tomato outbreak), and S. Poona LJH63I (human isolate from tomato outbreak). All five Salmonella serovars were obtained from L.J. Harris (University of California, Davis) and had been adapted to the antibiotic rifampicin by spontaneous mutation (Lindeman and Suslow, 1987). Tryptic soy broth (TSB) (BD Diagnostics, Franklin Lakes, N.J.) and tryptic soy agar (TSA) supplemented with $80 \mu \mathrm{g} \cdot \mathrm{mL}^{-1}$ rifampicin (rif+) were used to maintain and cultivate Salmonella cultures. All dilutions were performed in phosphate buffered saline (PBS) prepared from PBS tablets (ICN Biomedicals, Aurora, Ohio).

ACQUiSITION OF TOMATOES AND paCKING LINe materials. Domesticgrown, mature green harvested tomatoes (cv. Florida 47) obtained from DiMare (Tampa, Fla.) were used in all experimental studies. Tomato samples were removed from the packing line following washing but prior to the waxing process. Size classification of the tomatoes, according to the Florida Tomato Committee, was $6 \times 7 \mathrm{~cm}(57.9$ to $65.8 \mathrm{~mm}$ maximum diameter) (Florida Tomato Committee, 2002). Stainless steel (type 304, no.4 finish), conveyor belt material (proprietary composition; Tri-Pak Machinery, Harlingen, Texas), PVC, and sponge rollers (proprietary composition; Tri-Pak Machinery) were obtained from Tri-Pak Machinery. Unfinished oak wood pieces were obtained from a local home improvement warehouse. All materials were sized to $2.5 \times 2.5-\mathrm{cm}$ pieces and sterilized prior to use in experimental procedures. The stainless steel coupons were immersed in methanol and rinsed with deionized water to remove any residual oil from the surface prior to sterilization.

INOCULUM PREPARATION AND INOCULATION OF SAMPLES. Three days prior to each experiment, Salmonella cultures were individually cultivated $\left(37^{\circ} \mathrm{C}, 30 \mathrm{rpm}\right)$ in $10-\mathrm{mL}$ tubes of TSB rif+. Overnight transfers were performed using $10-\mu \mathrm{L}$ sterile, disposable loops (BD Diagnostics) in 10-mL tubes of TSB rif+ each day. On the day of the experiment, the Salmonella cocktail was complied by transferring $2.0 \mathrm{~mL}$ from each of the five 20-h Salmonella cultures (late stationary phase) to a clean, sterile $15-\mathrm{mL}$ centrifuge tube. The cocktail was centrifuged (4000 $\mathscr{g}_{\mathrm{n}}$ for $10 \mathrm{~min}$ ) and the resulting pellet was washed twice in $10 \mathrm{~mL}$ PBS. The cell titer of the prepared inoculum was determined by pour plate using TSA rif.

All tomatoes and packing line materials were placed in sterile fiberglass trays. Prior to inoculation, sponge roller pieces were dampened with sterile, deionized water to simulate the wet nature of sponge rollers in a typical tomato packinghouse. Ten $10-\mu \mathrm{L}$ aliquots of the prepared inoculum were spot inoculated around the blossom scar of tomatoes and on packing line materials at locations pre-marked with permanent black ink. Trays containing inoculated tomatoes and packing line materials were placed under a laminar flow hood and allowed to dry completely at room temperature for no longer than $2 \mathrm{~h}$. After the inoculum had dried completely, trays containing tomatoes and packing line materials were transferred to the environmental chamber.

Recovery of InOCUlum. Samples were aseptically transferred to sterile Stomacher bags (Seward Ltd., Thetford, England) containing $100 \mathrm{~mL}$ of sterile PBS on the appropriate day of sampling. Recovery of Salmonella from tomato and packing line materials was by vigorous shake/hand rub for 1 min (Burnett and Beuchat, 2001; Harris et al., 2002; Zhuang et al., $1995)$ concentrating on the area of inoculation, as marked by the permanent ink. In addition to the shake/rub method, inoculated sponge rollers were squeezed in the PBS rinse to recover Salmonella that may have migrated into the sponge matrix.

EXPERIMENTAL DESIgN. Twentyfour replicates of tomatoes and of each packing line material were inoculated as described above and placed in the environmental chamber at $30^{\circ} \mathrm{C} / 80 \%$ $\mathrm{RH}$ (Florida spring conditions). Three replicates of each sample were analyzed at days $0,1,3,7,11,14,21$ and 28 . Un-inoculated tomatoes were also analyzed to verify complete inhibition of background tomato microflora by TSA rift. On each day of sampling, inocula were recovered from tomatoes and packing line materials as described above. Serial dilutions from the PBS rinse were pour plated using TSA rif+. All TSA rif + plates were incubated at $37^{\circ} \mathrm{C}$ for $48 \mathrm{~h}$. The experiment was repeated for tomatoes and packing line materials using incubation at 20 ${ }^{\circ} \mathrm{C} / 60 \% \mathrm{RH}$ (Florida fall/winter conditions), and for tomatoes only at 20 ${ }^{\circ} \mathrm{C} / 90 \% \mathrm{RH}$ (standard ripening room conditions).

Statistical analysis. All data from Salmonella survival studies were recorded as colony forming units (cfu) per milliliter. Statistical analyses were performed using SAS (SAS Institute, Cary, N.C.). The GLM procedure in SAS was used to analyze changes of bacterial populations between replications in each experiment. Multiple comparisons were performed using 
the least squares mean adjusted by the Bonferroni method. Values of $P<0.05$ were considered significant.

\section{Results}

Preliminary studies verified that each of the Salmonella serovars grew to a cell titer at $20 \mathrm{~h}$ with no significant difference $(P<0.05)$ among serovars (data not shown). Analysis of PBS rinses from un-inoculated tomatoes verified the complete inhibition of natural tomato microflora by TSA rif+.

SURVIVAL OF SALMONELLA ON TOMATO SURFACES. Tomatoes held at $30{ }^{\circ} \mathrm{C} / 80 \% \mathrm{RH}$ (Florida spring), 20 ${ }^{\circ} \mathrm{C} / 60 \% \mathrm{RH}$ (Florida fall/winter), or $20 \mathrm{C} / 90 \% \mathrm{RH}$ (standard ripening room conditions) showed an overall decrease in Salmonella populations over the 28-d experiment (Fig. 1). For tomatoes held at $30{ }^{\circ} \mathrm{C} / 80 \% \mathrm{RH}$, Salmonella populations declined from $5.1 \log \mathrm{cfu} / \mathrm{mL}$ (day 0 ) to undetectable levels (day 21), however an unexpected increase to $1.2 \log \mathrm{cfu} / \mathrm{mL}$ was observed between day 21 and day 28. For tomatoes held at $20{ }^{\circ} \mathrm{C} / 60 \%$ $\mathrm{RH}$, Salmonella populations declined from $4.6 \log \mathrm{cfu} / \mathrm{mL}$ (day 0 ) to 1.5 $\log \mathrm{cfu} / \mathrm{mL}$ (day 28). For tomatoes held at $20{ }^{\circ} \mathrm{C} / 90 \% \mathrm{RH}$, Salmonella population declined from $4.6 \mathrm{log}$ $\mathrm{cfu} / \mathrm{mL}$ (day 0 ) to $1.4 \log \mathrm{cfu} / \mathrm{mL}$ (day 28). This study did not address the effect of ethylene on Salmonella survival on tomato surfaces at ripening room conditions. At the end of the 28-d study, Salmonella survived on tomato surfaces in populations with no significant difference $(P<0.05)$ among temperature and $\mathrm{RH}$ combinations. As the experiment progressed, tomatoes held at $30{ }^{\circ} \mathrm{C} / 80 \% \mathrm{RH}$ developed an orange color due to inhibition of lycopene biosynthesis during ripening (Masarirambi et al., 1995), more so than tomatoes held at $20^{\circ} \mathrm{C} / 60 \% \mathrm{RH}$ or $20{ }^{\circ} \mathrm{C} / 90 \% \mathrm{RH}$.

SuRVIVAL OF SALMONELLA ON PACKING LINE MATERIALS. All packing materials tested at $30{ }^{\circ} \mathrm{C} / 80 \% \mathrm{RH}$ (Florida spring) or $20{ }^{\circ} \mathrm{C} / 60 \% \mathrm{RH}$ (Florida fall/winter) showed an overall decrease in Salmonella populations over the 28-d experiments (Fig. 2).

Stainless steel supported Salmonella survival when held at $20^{\circ} \mathrm{C} / 60 \%$ $\mathrm{RH}$, but not at $30^{\circ} \mathrm{C} / 80 \% \mathrm{RH}$ over the 28-d study (Fig. 2A). When stainless steel surfaces were held at $20{ }^{\circ} \mathrm{C} / 60 \%$ $\mathrm{RH}$, Salmonella populations declined from $4.4 \log \mathrm{cfu} / \mathrm{mL}$ at day 0 to 0.7

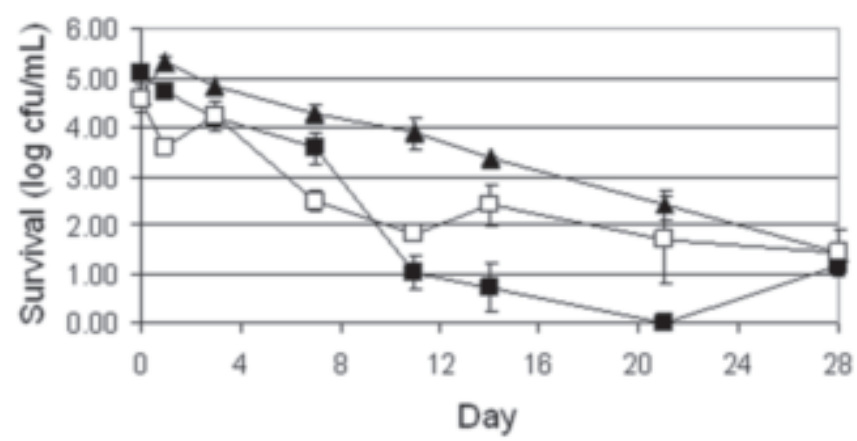

Fig. 1. Populations of Salmonella declined over time on tomato surfaces. Tomatoes were artificially inoculated with a five serovar (serotype), rifampicin-resistant Salmonella cocktail and held at various temperature/relative humidity $(\mathrm{RH})$ combinations: (口) $30{ }^{\circ} \mathrm{C} / 80 \% \mathrm{RH}$ (Florida spring), ( $\square$ ) $20{ }^{\circ} \mathrm{C} / 60 \% \mathrm{RH}$ (Florida fall/winter), and (A) $20{ }^{\circ} \mathrm{C} / 90 \% \mathrm{RH}$ (standard ripening room conditions). On each day of sampling, inocula were recovered from three replicate tomatoes via a vigorous shake-rub method and enumerated by pour plate using tryptic soy agar supplemented with $80 \mu \mathrm{g} \cdot \mathrm{mL}^{-1}(\mathrm{ppm})$ rifampicin $(1 \mathrm{~mL}=0.0338 \mathrm{fl} \mathrm{oz})$.

$\log \mathrm{cfu} / \mathrm{mL}$ on day 28 . When stainless steel surfaces were held at $30{ }^{\circ} \mathrm{C} / 80 \%$ $\mathrm{RH}$, however, Salmonella populations decreased from $4.4 \log \mathrm{cfu} / \mathrm{mL}$ at day 0 to undetectable levels at day 11 , and then remained undetectable for the remainder of the 28 -d study. These data demonstrate the ability of stainless steel to support long-term survival of Salmonella populations given favorable temperature and relative humidity.

Conveyor belt material did not support Salmonella survival when held at $20^{\circ} \mathrm{C} / 60 \% \mathrm{RH}$ or $30^{\circ} \mathrm{C} / 80 \% \mathrm{RH}$ over the 28 -d study (Fig. 2B). When conveyor belt surfaces were held at $20{ }^{\circ} \mathrm{C} / 60 \% \mathrm{RH}$, Salmonella populations declined from $4.3 \mathrm{log} \mathrm{cfu} / \mathrm{mL}$ at day 0 to undetectable levels on day 21. When conveyor belt material was held at $30{ }^{\circ} \mathrm{C} / 80 \% \mathrm{RH}$, Salmonella populations decreased from $4.1 \mathrm{log}$ $\mathrm{cfu} / \mathrm{mL}$ at day 0 to undetectable levels at day 3 , and then remained undetectable for the remainder of the 28-d study. These data demonstrate that conveyor belt material does not support the long-term survival of Salmonella populations, especially at temperature/relative humidity conditions of the spring tomato production season in Florida.

PVC surfaces supported Salmonella survival when held at $20^{\circ} \mathrm{C} / 60 \%$ RH over the 28-d study, but those at $30{ }^{\circ} \mathrm{C} / 80 \% \mathrm{RH}$ did not (Fig. 2C). When PVC surfaces were held at 20 ${ }^{\circ} \mathrm{C} / 60 \% \mathrm{RH}$, Salmonella populations declined from $5.1 \log \mathrm{cfu} / \mathrm{mL}$ at day 0 to $0.6 \log \mathrm{cfu} / \mathrm{mL}$ on day 28 , however, when held at $30{ }^{\circ} \mathrm{C} / 80 \% \mathrm{RH}$, Salmonella populations decreased from 5.1 $\log \mathrm{cfu} / \mathrm{mL}$ at day 0 to undetectable levels at day 11 , and then remained undetectable for the remainder of the 28-d study. These data demonstrate the ability of PVC surfaces to support long-term survival of Salmonella populations given favorable temperature and relative humidity.

Sponge roller surfaces did not support Salmonella survival when held at $20{ }^{\circ} \mathrm{C} / 60 \% \mathrm{RH}$ or $30^{\circ} \mathrm{C} / 80 \% \mathrm{RH}$ over the 28-d study (Fig. 2D). When sponge roller surfaces were held at 20 ${ }^{\circ} \mathrm{C} / 60 \% \mathrm{RH}$, Salmonella populations declined from $4.1 \log \mathrm{cfu} / \mathrm{mL}$ at day 0 to undetectable levels on day 7 . When sponge roller surfaces were held at 30 ${ }^{\circ} \mathrm{C} / 80 \% \mathrm{RH}$, Salmonella populations decreased from $5.0 \log \mathrm{cfu} / \mathrm{mL}$ at day 0 to undetectable levels at day 1 , and then remained undetectable for the remainder of the $28-\mathrm{d}$ study. These data demonstrate that sponge roller surfaces do not support the survival of Salmonella populations at temperature/relative humidity conditions of the spring or fall/winter tomato production seasons in Florida.

Unfinished wood surfaces supported Salmonella survival when held at $20{ }^{\circ} \mathrm{C} / 60 \% \mathrm{RH}$, but not at 30 ${ }^{\circ} \mathrm{C} / 80 \% \mathrm{RH}$ over the 28 -d study (Fig. $2 \mathrm{E})$. When the wood surfaces were held at $20{ }^{\circ} \mathrm{C} / 60 \% \mathrm{RH}$, Salmonella populations declined from $3.2 \mathrm{log}$ $\mathrm{cfu} / \mathrm{mL}$ at day 0 to $1.7 \log \mathrm{cfu} / \mathrm{mL}$ on day 28. When they were held at $30{ }^{\circ} \mathrm{C} / 80 \% \mathrm{RH}$, however, Salmonella populations decreased from $4.7 \mathrm{log}$ $\mathrm{cfu} / \mathrm{mL}$ at day 0 to undetectable levels at day 7. Unexpectedly, Salmonella at $1.0 \mathrm{cfu} / \mathrm{mL}$ was detected on day 

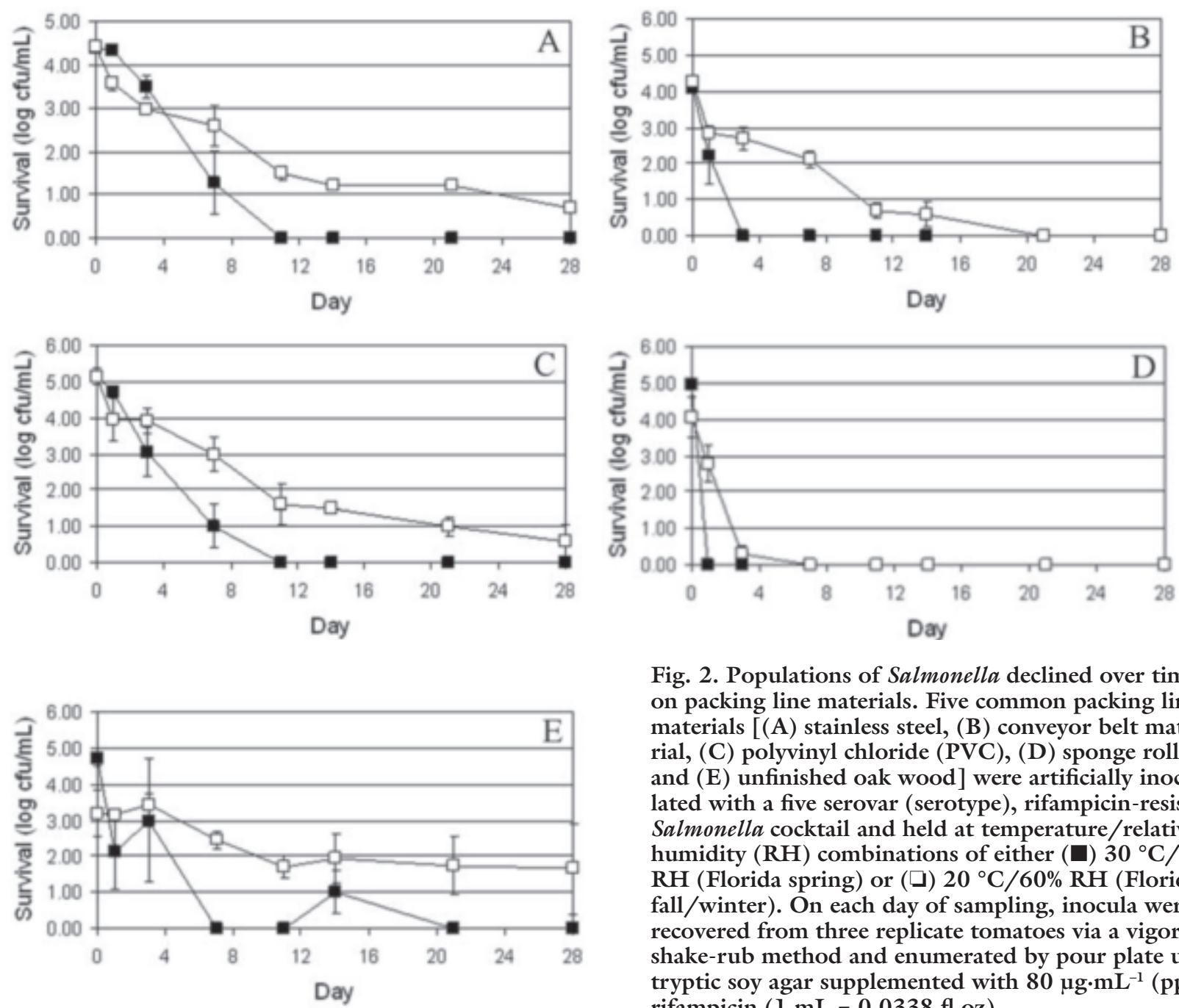

Fig. 2. Populations of Salmonella declined over time on packing line materials. Five common packing line materials [(A) stainless steel, (B) conveyor belt material, (C) polyvinyl chloride (PVC), (D) sponge rollers, and $(\mathrm{E})$ unfinished oak wood] were artificially inoculated with a five serovar (serotype), rifampicin-resistant Salmonella cocktail and held at temperature/relative humidity $(\mathrm{RH})$ combinations of either $(\square) 30{ }^{\circ} \mathrm{C} / 80 \%$ $\mathrm{RH}$ (Florida spring) or $(\square) 20{ }^{\circ} \mathrm{C} / 60 \% \mathrm{RH}$ (Florida fall/winter). On each day of sampling, inocula were recovered from three replicate tomatoes via a vigorous shake-rub method and enumerated by pour plate using tryptic soy agar supplemented with $80 \mu \mathrm{g} \cdot \mathrm{mL}^{-1}(\mathrm{ppm})$ rifampicin $(1 \mathrm{~mL}=0.0338 \mathrm{fl} \mathrm{oz})$.

14, however undetectable levels were again observed on day 21 and day 28 . These data demonstrate the ability of unfinished oak wood surfaces to support long-term survival of Salmonella populations given favorable temperature and relative humidity.

\section{Discussion}

The five-serovar Salmonella cocktail used in these inoculated trials was in compliance with previous recommendations for the analysis of microbial hazards on fresh produce [U.S. Food and Drug Administration (FDA), 2001]. The rub-shake method employed for inoculum recovery was currently the most effective protocol for removing microorganisms from the surfaces of whole fruits and vegetables, such as tomatoes (FDA, 2001). Spot inoculation was chosen over dip or spray inoculation procedures to enable the delivery of known populations directly to the sample surface. It is noted that the use of PBS as an inoculum carrier is somewhat controversial; however sufficient Salmonella populations survived the drying process in the presence of PBS salts, thereby allowing the successful monitoring of population levels over time.

Results of this study suggest that Salmonella can survive on tomato surfaces for long periods of time. Salmonella populations decreased approximately $3.0 \log \mathrm{cfu} / \mathrm{mL}$ over $28 \mathrm{~d}$ regardless of the temperature/relative humidity. These results are in agreement with previous reports of Salmonella survival on tomato surfaces (Guo et al., 2002). The highest number of Salmonella recovered on any given day of sampling was for tomatoes held at standard ripening room conditions $(20$ $\left.{ }^{\circ} \mathrm{C} / 90 \% \mathrm{RH}\right)$. On day 11, Salmonella populations were significantly higher $(P$ $<0.05)$ on tomatoes held at standard ripening room conditions. These data suggest that high humidity common to tomato ripening rooms in combination with ambient temperature may support greater survival of Salmonella in short-term holding situations. Since Salmonella survival on tomato surfaces held at $20{ }^{\circ} \mathrm{C} / 90 \% \mathrm{RH}$ more closely resembles survival on tomato surfaces held at $20{ }^{\circ} \mathrm{C} / 60 \% \mathrm{RH}$ rather than at $30{ }^{\circ} \mathrm{C} / 80 \% \mathrm{RH}$, temperature may be a more important factor than relative humidity for long-term survival under the conditions tested.

Packing line materials investigated were stainless steel, conveyor belt material, PVC, sponge rollers, and unfinished oak. Stainless steel is a smooth, easily sanitized surface, widely recognized as an excellent material for the food industry (Midelet and Carpentier, 2002). It is commonly used in the manufacture of dump tanks, processing lanes, and most equipment in tomato 
packinghouses. Conveyor belts used in the transfer of tomatoes throughout the packing line are typically made of rubber compounds (composition not disclosed by manufacturer). PVC is commonly used to cover roller bars that move tomato fruits along processing lines smoothly to prevent extensive bruising and injury. Sponge rollers remove free water from tomatoes following the washing operation and prior to drying. Finally, wooden field bins and pallets used in tomato packinghouse facilities are usually constructed from unfinished oak wood.

Results of this study suggest that Salmonella can survive on packing line materials for longer periods of time in the cooler, Florida fall/winter tomato production season than in the warmer, Florida spring tomato production season. When held at Florida spring conditions, Salmonella populations reached undetectable levels by day 11 , $3,11,1$, and 7 for stainless steel, conveyor belts, PVC, sponge rollers, and unfinished oak surfaces, respectively. In comparison, Salmonella populations held at Florida fall/winter conditions never declined to undetectable levels on stainless steel, PVC, and unfinished wood surfaces; undetectable levels were reached on conveyor belt and sponge roller surfaces on day 21 and day 7 , respectively.

Compositional differences among packing line materials may have influenced Salmonella survival and/or recovery. Unlike the other materials tested, stainless steel and PVC have nonporous, hydrophobic surfaces (Midelet and Carpentier, 2002). Nevertheless, grooves and crevices in stainless steel (type 304, no. 4 finish) can be seen using scanning electron photomicrographs (Mafu et al., 1990). PVC also contains microscopic holes and crevices, but it is more likely to bend or accumulate cracks or holes than stainless steel. Hydrophobic qualities accompanied with the dense nature of stainless steel and PVC most likely prevented Salmonella from migrating far from the point of inoculation. Salmonella survival and recovery on stainless steel and PVC were similar at both environmental conditions tested (see Fig. 2A and C, respectively). Rubber conveyor belt surfaces, while smooth to the touch, contain crevices and holes when analyzed by scanning electron pictographs
(Mafu et al., 1990). Sponge rollers and unfinished oak wood are porous by nature and readily soaked up inoculated Salmonella. The poor recovery of Salmonella observed with conveyor belt and sponge roller materials suggests that these materials do not support the survival of Salmonella spp. (Fig. $2 \mathrm{~B}$ and $\mathrm{D}$, respectively). Recovery of Salmonella from unfinished wood was the most variable of the materials tested (Fig. 2E). The inoculum may have soaked into the interior of the oak pieces, preventing consistent recovery due to the inability to squeeze the PBS rinse through the matrix.

Without an adequate sanitation program, sponge rollers in operational tomato packing lines may facilitate survival of Salmonella over what was observed in this study. In addition to recovery issues discussed above, sponge rollers in packinghouse environments tend to retain water and soil. In order to simulate packinghouse conditions in this study, sterile water was added to the sponge rollers prior to inoculation, however no soil was added. Previous studies by Guo et al. (2002) reported Salmonella survival in moist soil for $45 \mathrm{~d}$, therefore sponge rollers in packing lines may provide a more favorable environment for Salmonella survival than the clean, un-used sponge rollers investigated in this study. Furthermore, water was only added at day 0 , therefore the amount of moisture retained over several days in this study may be lower than that found on sponge rollers on an operational packing line.

In conclusion, Salmonella survived $28 \mathrm{~d}$ on tomato surfaces when held at temperature and relative humidity combinations simulating the Florida spring tomato production season, the Florida fall/winter tomato production season, and standard ripening room conditions. In general, Salmonella did not persist on packing line materials when held at conditions of the Florida spring tomato production season. Stainless steel, PVC, and unfinished wood supported the survival of Salmonella over $28 \mathrm{~d}$ at conditions of the Florida fall/winter tomato production season, while conveyor belt and sponge roller materials did not. This study highlights the importance of maintaining sanitary conditions within the packinghouse in order to minimize the risk of Salmonella contamination.

\section{Literature cited}

Abdul-Raouf, U.M., L.R. Beuchat, and M.S. Ammar. 1993. Survival and growth of Escherchia coli O157:H7 on salad vegetables. Appl. Environ. Microbiol. 59:1999-2006.

Blostein, J. 1991. An outbreak of Salmonella javiana associated with consumption of watermelon. J. Environ. Health 56:29-31.

Burnett, A.B. and L.R. Beuchat. 2001. Comparison of sample preparation methods for recovering Salmonella from raw fruits, vegetables and herbs. J. Food Protection 64:1459-1465.

Centers for Disease Control and Prevention. 1979. Salmonella Oranienburg gastroenteritis associated with the consumption of precut watermelons. Morbidity Mortality Weekly Rpt. 28:522-523.

Centers for Disease Control and Prevention. 2002. Outbreak of Salmonella javiana infection-Orlando, Florida, June 2002. Morbidity Mortality Weekly Rpt. 51:683-684.

Centers for Disease Control and Prevention. 2004a. Preliminary FoodNet Data on the incidence of infection with pathogens transmitted commonly through food-Selected sites, United States, 2003. Morbidity Mortality Weekly Rpt. 53:338-343.

Centers for Disease Control and Prevention. 2004b. Summary of notifiable diseases-United States, 2002. Morbidity Mortality Weekly Rpt. 51:1-84.

Cummings, K., E. Barrett, J.C. MohleBoetani, J.T. Brooks, J. Farrar, T. Hunt, A. Fiore, K. Komatsu, B. Werner, and L. Slutsker. 2001. A multi-state outbreak of Salmonella enterica serotype baildon associated with domestic raw tomatoes. Emerging Infectious Dis. 7:1046-1048.

Florida Tomato Committee. 2002. Florida tomato facts and sizing. 29 Mar. 2005. <http://www.floridatomatoes.org/facts. html>.

Gayler, G.E., R.A. MacCready, J.P. Reardon, and B.F. McKernan. 1955. An outbreak of salmonellosis traced to watermelon. Public Health Rpt. 70:311-313.

Golden, D.A., E.J. Rhodehamel, and D.A. Kautter. 1993. Growth of Salmonella spp. in cantaloupe, watermelon and honeydew melons. J. Food Protection 56:194-196.

Guo.X., J. Chen, R.E. Brackett, and L.R. Beuchat. 2001. Survival of samonellae on and in tomato plants from the time of inoculation at flowering and early stages of fruit development through fruit ripening. Appl. Environ. Microbiol. 67:4760-4764. 
Guo, X., J. Chen, R.E. Brackett, and L.R. Beuchat. 2002. Survival of Salmonella on tomatoes stored at high relative humidity, in soil and on tomatoes in contact with the soil. J. Food Protection 65:274-279.

Harris, L.J., D. Zagory, and J.R. Gorny. 2002. Safety factors, p. 301-313. In: A.A. Kader (ed.). Postharvest technology of horticultural crops. 3rd ed. Univ. of California, Agr. and Natural Resources, Publ. 3311.

Hedburg, C.W., F.J. Angulo, K.E. White, C.W. Langkop, W.L. Schell, M.G. Stobierski, A. Schutat, J.M. Besser, S. Dietrich, L. Helsel, P.M. Griffin, J.W. McFarland, M.T. Osterholm, and the Investigation Team. 1999. Outbreaks of salmonellosis associated with eating uncooked tomatoes: Implications for public health. Epidemiology Infection 122:135-393.

Lindeman, J. and T. Suslow. 1987. Competition between ice nucleation active wildtype and ice nucleation deficient deletion mutant strains of Pseudomonassyringae and P. fluorescens biovar I and biological control of frost injury on strawberry blossoms. Phytopathology 7:882-886.

Lucier, G., L. Biing-Hwan, J. Allhouse, and L.S. Kantor. 2000. Factors affecting tomato consumption in the United States. 29 Mar. 2005. <http://www.ers.usda. gov/briefing/consumption/gallery/TomatoConsumption.pdf $>$.

Lukasik, J., M.L. Bradley, T.M. Scott, W. Hsu, S.R.Farrah, and M.L. Tamplin. 2001. Elution, detection, and quantification of polio 1, Bacteriophages, Salmonella Montevideo, and Escherchia coli O157:H7 from seed strawberries and tomatoes. J. Food Protection 64:292-297.
Mafu, A.A., D. Roy, J. Goulet, and P. Magny. 1990. Attachment of Listeria monocytogenes to stainless steel, glass, polypropylene and rubber surfaces after short contact times. J. Food Protection 53:742-746.

Masarirambi, M.T., J.K. Brecht and S.A. Sargent. 1995. Tomato color development following exposure to ethylene at high temperatures. Proc. Fla. State Hort. Soc. 108:268-272.

Midelet, G. and B. Carpetier. 2002. Transfer of microorganisms, including Listeria monocytogenes from various materials to beef. Appl. Environ. Microbiol. 68:4015-4024.

O'Mahoney, M., J. Cowden, B. Smyth, D. Lynch, M. Hall, B. Rowe, E.L. Teare, R.E. Tettmar, A.M. Rampling, and M. Coles. 1990. An outbreak of Salmonella saintpaulinfection associated with beansprouts. Epidemiology Infection 104:229-235.

U.S. Dept. of Agriculture. 2004. Tomatoes: Background. U.S. Dept. Agr., Econ. Res. Serv. 17 May 2005. <http://www. ers.usda.gov/Briefing/tomatoes/background.htm>.

U.S. Food and Drug Administration. 2001. Analysis and evaluation of preventative control measures for the control and reduction/elimination of microbial hazards on fresh and fresh-cut produce. 29 Mar. 2005. <http://www.cfsan.fda.gov/ comm>.

University of Florida. 2004. Florida automated weather network. 17 May 2005. <http://www.fawn.ifas.ufl.edu>

Zhuang, R.Y., L.R. Beuchat, and F.J. Angulo. 1995. Fate of Salmonella montevideo on and in raw tomatoes as affected by temperature and treatment with chlorine. Appl. Environ. Microbiol. 61:2127-2131. 